\title{
Anticancer Studies of Extracts and Fractions of Hertia Intermedia
}

\author{
Hakeemullah ${ }^{1}$, Muhammad Anwar ${ }^{1}$, Jahangir Khan ${ }^{1}$, \\ Inayatullah$^{1}$, Naqeebullah Khan ${ }^{2, *}$, Abdul Hakeem² \\ ${ }^{1}$ Institute of Biochemistry, University of Balochistan, Quetta 87300-Pakistan \\ ${ }^{2}$ Department of chemistry, University of Balochistan, Quetta 87300-Pakistan
}

\begin{tabular}{ll}
\hline Articles Information & Abstract \\
& \\
Received: & This study was conducted to prepare the extract from medicinal plant Hertia \\
$04,12,2019$ & intermedia and its evaluation for presence of anticancer activity. The medicinal \\
Accepted: & plant was collected and shade dried then crushed to convert it into powdered \\
$29,12,2019$ & form. The powdered form of the plant was soaked for 15 days in an organic \\
Published: & solvent methanol $\left(\mathrm{CH}{ }_{3} \mathrm{OH}\right)$. The extract obtained passed through the filtration \\
01, March, 2020 & process followed by vaporization of the residual solvent using rotary evaporator. \\
& The methanol extract of Hertia Intermedia was used to prepare different \\
& fractions of solvent using aqueous dichloromethane, benzene, butanol, \\
Keywords: & chloroform, ethyl acetate and n-hexane. Methanol extract, aqueous extract, \\
Hertia Intermedia & butanol extract and extract of Hertia intermedia did not show any activity \\
Methanolic extract & against cancerous cell lines. Hertia intermedia did not show any noticeable \\
3 T3 & activity and remains inactive ROS against HeLa cell line, 3T3 cell line, MCF-7 \\
MCF-7 & cell line (cancerous cell). Hertia intermedia did not contain any bioactivity \\
Hela & against cancerous or reactive oxygen species which is the initiator or producing \\
Cell lines & cancer.
\end{tabular}

DOI: $10.22401 /$ ANJS.23.1.06

* Corresponding author: naqeebhmd2@gmail.com

\section{Introduction}

Cancer in the modern world is a well-known dangerous disease. Cell proliferates itself in uncontrolled manner resulting in cancer. Tumor is also a type of cancer characterized by formation of cluster of mass consisting of abnormal cells. Cancers continue to grow through a process called metastasis. Malignant cells travel through the lymphatic or blood vessels eventually forming new tumors in other parts of the body [1]. Cancer is the second most commonly occurring cancer in females and males after lung and prostate cancers. In 2018, the worldwide prevalence of colon cancer in both male and female was $\sim 1.85$ million with 880,792 deaths globally [2].

From the ancient time before the advent of scientific upheaval, therapeutically active plants were used as sole remedies against the diseases. Natural ingredients present in plant extracts were considered to act as a rebound and home grown recovery from the diseases going round off the globe [3]. The naturally grown medicinal plants were considered yields better results in comparison with the synthetics items for person and their condition. The natural herbs such as Catharanthus roseus, Podophyllum plant species (Berberidaceae) etc. had been assessed for their medicinal activity, incarnation and fragrant characteristics for long time [4]. With the passage of time the blind dependence on synthetic remedies is reverted and researchers and people believe back to the older concept of treatment using natural sources and plants. Now mostly depend principally on plants and plant extracts for the wellbeing of mankind. Over 30\% of the entire plant species were used for restorative judgments. According to some studies until now approximately 90 species of plants have been investigated for any known therapeutic activity [5]. Out of which 120 therapeutic plants drugs of known pharmacology and structure are being discovered till now. Among those therapeutic agents some of the most imperative plant drugs include Camptotecin, Digitoxigenin, morphine, atropine, vincristine, vinblastine, Taxol, Podophyllotoxingitxigenin, Digoxigenin, 


\section{Al-Nahrain Journal of Science}

ANJS, Vol.23 (1), March, 2020, pp. 43 - 46

Tubocurarine, codeine, Artemesininaspirin, pilocarpine, Capsaicin, Allicin, curcuma, ephedrine and Capparisspinosa. [6]. Moreover, the extraction of the active principle of a drug and its isolation and identification is considered to be of great importance. Consequently, works in both determinations of single active compound or combination of traditional drugs is very significant. The active ingredient of the plant must be obtained from the natural plant material because the active molecule cannot be manufactured synthetically [7]. Thus the scientific study of ancient medicines, drugs derivation through bio prospecting and organized conservation of the related medicinal plants is of great significance. Therefore, medicinal plants are the ray of hope for diagnosing complicated ailment encountered by human body [8]. In this modern era the whole global is depending mainly on convention of traditional medicinal plants. In case of disease like cancer the medicinal plants are so effective and easily accessible for extraction of chemotherapeutic agents for diagnosis as well as treatment. Chemotherapeutic agents are timely response against cancerous cells but they are neither effective nor curable [9]. It is indeed the miracle of traditional plants via biotechnological tools and research that mankind are taking advantage of that very effective plants and replacing temporarily and life taking technique chemotherapy. The chemical constituents present in these medicinal plants are utilized with least toxicity and reactions [10]. Ethno therapeutic plants are being used for the management of many maladies [11]. Clan Senecioneae, family Composite involves the significant class Hertia which includes almost 12 species, present in South west Asia and north and south of Africa [12]. Othonnopsis intermedia is the discretionary name of Hertia intermedia which is found in Balochistan in Killa Abdullah, Pishin, Chaman, Quetta, Khanozai. Hertia intermedia is minor bush with blooms of yellow shading [13]. The therapeutic plant, Hertia intermedia is generally used as an analgesic in Pakistan. The phytochemicals present in the plants are known as hertidins [14]. The phytochemicals belong to terpenoids, tannins, flavonoids, coumarins, and steroids [15]. The local cultivators and experienced elderly of the general public are the conventional specialists from whom individuals look for treatment and advices regarding plant and its uses [16].

\section{Materials and Method}

\section{Identification and Collection of Plant}

The plant Hertia Intermedia was collected from the selected areas such as Killa Abdullah, Pishin and Bostan and then brought to the laboratory of institute of biochemistry, University of Balochistan, Quetta, Pakistan and later on HEJ laboratory Karachi University for bioactivity analysis.

\section{Preparation of Extract}

The extraction and fractionation of Hertia intermedia was done. The plant Hertia intermedia was collected and dried for a month. The dried plant was ground into a fine powder with help of mortar and pestle. The measured amount of $3 \mathrm{~kg}$ dried powder was taken and soaked in 10 liters of methanol for fifteen days. Later, the filtration was conducted by using Whatman no 42 filter paper for obtaining the extract. The extract obtained after a week was filtered to remove any residual impurities and the liquid was vaporized using rotary evaporator. The extract obtained after vaporization was $104 \mathrm{gm}$ which was further fractionated with $\mathrm{n}$-hexane and aqueous medium to obtain $\mathrm{n}$-hexane fraction $6.5 \mathrm{gm}$. and aqueous fraction $35 \mathrm{gm}$. aqueous fraction was further diluted with butanol to prepare butanol fraction 3 gm [5].

\section{Results and Discussion}

The dilutions of the Hertia Intermedia extract were prepared using different concentration for the testing of bioactivity against cancerous cells. To perform the test four concentrations using Hertia intermedia extract were prepared using methanol, aqueous, butanol and n-hexane extracts. Natural products are thought to possess anticancer activity with great effectiveness and less venomousness [17]. Several drugs that are being used for the treatment of cancer in recent time have been extracted from the natural products and plant [18].

\footnotetext{
Hertia intermedia Activity Against 3T3 Cell line The prepared concentrations of extract were screened against different cancer cell lines to check the activity using different concentration of the extract. The concentration of $30 \mu \mathrm{m}$ was used for each assay. The fractions coded as methanol fraction and hexane fraction of Hertia Intermedia shows inhibition against $3 \mathrm{~T} 3$ cell line as $10.7 \%$ and $12 \%$ respectively, whereas, the fraction coded as
} 


\section{Al-Nahrain Journal of Science}

ANJS, Vol.23 (1), March, 2020, pp. 43 - 46

aqueous fraction and butanol fraction of Hertia Intermedia revealed $31.6 \%$ and $12.5 \%$ against the same cell line as shown in Table 1.

\section{Hertia intermedia Activity against Hela cell line} Likewise, all the fractions having different concentrations were tested against Hela cell line [19]. The rate of inhibition of methanol fraction, hexane fraction of Hertia Intermedia was found as $8.4 \%$ and $30 \%$ while aqueous fraction and butanol fraction of Hertia Intermedia indicated the inhibition of $31.6 \%$ and $29.3 \%$ respectively as described in Table 2.

Hertia Intermedia Activity against MCF-7 Cell line The fractions of the extracts were tested against cell line named as MCF-7 cell line. The methanol fraction and hexane fraction of Hertia Intermedia exhibited $3.4 \%$ and $23.0 \%$ inhibition whereas aqueous fraction and butanol fraction of Hertia Intermedia showed $29.4 \%$ and $36.2 \%$ inhibition as shown in Table 3.

Table 1: Hertia intermedia inhibition against 3T3 cell line

\begin{tabular}{|c|c|c|c|}
\hline Sample Codes & Conc. ( $\mathrm{mm})$ & Inhibition \% age & $\mathrm{IC}_{50} \pm \mathrm{SD}$ \\
\hline MF & 30 & $-10.7 \%$ & Inactive \\
\hline $\mathrm{HF}$ & 30 & $-12.0 \%$ & Inactive \\
\hline $\mathrm{AF}$ & 30 & $31.6 \%$ & Inactive \\
\hline $\mathrm{BF}$ & 30 & $12.5 \%$ & Inactive \\
\hline
\end{tabular}

Table 2: Hertia intermedia inhibition against Hela cell line

\begin{tabular}{|c|c|c|c|}
\hline Sample Codes & Conc. $(\mu \mathrm{m})$ & Inhibition \% age & $\mathrm{IC}_{50} \pm \mathrm{SD}$ \\
\hline $\mathrm{MF}$ & 30 & $-8.4 \%$ & Inactive \\
\hline $\mathrm{HF}$ & 30 & $-30.0 \%$ & Inactive \\
\hline $\mathrm{AF}$ & 30 & $36.0 \%$ & Inactive \\
\hline $\mathrm{BF}$ & 30 & $29.3 \%$ & Inactive \\
\hline
\end{tabular}

Table 3: Hertia intermedia inhibition against MCF-7 cell line

\begin{tabular}{cccc}
\hline \multirow{2}{*}{ Sample Codes } & Conc. $(\boldsymbol{\mu m})$ & Inhibition \% age & IC $_{50} \pm$ SD \\
\hline MF & 30 & $-3.4 \%$ & Inactive \\
HF & 30 & $-23.0 \%$ & Inactive \\
AF & 30 & $29.4 \%$ & Inactive \\
BF & 30 & $36.2 .3 \%$ & Inactive \\
\hline MF & methanol fraction, HF & hexane fraction, \\
AF & aqueous fraction, BF & butanol fraction
\end{tabular}

\section{Conclusions}

In this research study, the extract and fractions prepared using medicinal plant Hertia intermedia whereas evaluated and tested for anticancer activity against 3T3 cell line, HeLa cell line, MCF-7 cell line using different dilutions of methanol, aqueous solvent, butanol and $\mathrm{n}$-hexane containing fixed ratio of Hertia intermedia extract. The results revealed that there was no noticeable bioactivity observed against different cancer cell line so we concluded that Hertia intermedia is inactive against cancer cell lines and do not have any chemotherapeutic effect.

\section{Acknowledgement}

The authors are very grateful to the institute of Biochemistry, University of Balochistan, Quetta Pakistan, HEJ Karachi University and authors acknowledged the help taken from others and express their thankfulness to a great help from the University that made the crucial laboratory facilities available. 


\section{Al-Nahrain Journal of Science}

ANJS, Vol.23 (1), March, 2020, pp. $43-46$

\section{References}

[1] Aziz, M. A.; Khan, A. H.; Adnan, M.; Izatullah, I.; "Reported the traditional uses of medicinal plants by the native communities and local herbal practitioners of Bajaur Agency, Federally Administrated Tribal Areas"; Pakistan J. Ethnopharma-col. 198, 268-281, 2017.

[2] Samiullah, S. K.; Rasool, B. T.; Naqeebullah, K.; Samina, A.; Fariha, A.; Saleha, S.; "Study of Phytochemistry and Antioxidant Activity of Hertia intermedia (Boiss.) Flowers of Balochistan Lasbela"; U. J. Sci. Technol., 92-100, 2015.

[3] Desai, A. G.; Qazi, G. N.; Ganju, R. K.; El-Tamer, M.; Singh, J.; Saxena, A. K.; Bhat, H. K.; "Medicinal plants and cancer chemoprevention"; Curr. Drug metabolism 9, 581-591, 2008.

[4] Singh, S. S.; Pandey, S. C.; Srivastava, S.; Gupta, S.; Patro, B.; Ghosh, A. C.; "Tinospora Cordifolia: Chemistry and Medicinal Properties"; Ind. J. Pharm 35, 83-91, 2003.

[5] Gordaliza, M.; "Natural products as leads to anticancer drugs"; Clinical and Translational Oncology 9, 767-776, 2007.

[6] Al-Janabi, N. M.; Al-Halbosiy, M. M.; Al-Badri, S. R.; "The Inhibitory Action of Capparisspinosa Leaves sagainst the Tumor and Leishmania"; $\mathrm{Al}-$ Nahrain J. Sci. 0(2), 53-58, 2019.

[7] Allawi, M. H.; Abed, M. Q.; "A Study of Anticancer Activity for Partial Purified Urease Isolated from Lagonychium farctum Plant"; Al-Nahrain J. Sci. 0(1), 95-99, 2018.

[8] Rashmi, R.; Kumar, S.; Karunagaran, D.; "Ectopic expression of Hsp70 confers resistance and silencing its expression sensitizes human colon cancer cells to curcumin - induced apoptosis"; Carcinogenesis 25, 179-187, 2004.

[9] Ikezaki, S.; Nishikawa, A.; Furukawa, F.; Kudo, K.; Nakamura, H.; Tamura, K.; Mori, H.; "Chemopreventive effects of curcumin on glandular stomach carcinogenesis induced by $\mathrm{N}$ Methyl-N'-nitro-N-nitrosoguanidine and sodium chloride in rats"; Anticancer Research 21, 34073411, 2001.

[10] Damjanović, A.; Zdunić, G.; Šavikin, K.; Mandić, B.; Jadranin, M.; Matić, I. Z.; Stanojković, T.;
"Evaluation of the anti-cancer potential of Mahonia aquifolium extracts via apoptosis and anti-angiogenesis"; Bangladesh J. Pharma. 11, 741-749, 2016.

[11] Sultana, S.; Asif, H. M.; Nazar, H. M.; Akhtar, N.; Rehman, J. U.; Rehman, R. U.; "Medicinal plants combating against cancer-a green anticancer approach" Asian Pac. J. Cancer Prev. 15, 4385-94, 2014.

[12] Akhgar, M. R.; Akhgar, D.; Ghazanfari, M.; Shariatifar; "Chemical composition and antibacterial activity of the leaf essential oil from Hertia intermedia"; Chem. Nat. Compd. 48, 2, 2015.

[13] Hashemi, A.; Abediankenari, S.; "Suppressive effect of Fig (Ficus carica) latexon esophageal cancer cell proliferation"; Acta Facultatis Med. Naissensis 30, 93, 2013.

[14] Jahangir, K. A.; Muhammad, A. P.; Abdul, M. K.; Ajab, K. T.; Nazima, Y. K.; Javed, K.; Asmatullah, K.; Samiullah, G.; "Analysis and Antileishmanial activity of dichloromethane fraction of Allium cepa (DFAC) in Vitro"; Internat. J. Pharma. Sci. Bio. 7, 40-5, 2016.

[15] Sultana, S.; Asif, H. M.; Nazar, H. M.; Akhtar, N.; Rehman, J. U.; Rehman, R. U.; "Medicinal plants combating against cancer-a green anticancer approach"; Asian Pac. J. Cancer. Prev. 15, 438594, 2014

[16] Sheeja, L.; Lakshmi, D.; Bharadwaj, S.; Parveen, K. S.; "Anticancer activity of phytol purified from Gracilaria edulis against human breast cancer cell line (MCF-7)"; Int. J. Curr. Sci. 19, 36-46, 2016.

[17] Hashemi, S. A.; Abediankenari, S.; "Suppressive effect of fig (Ficus carica) latex on esophageal cancer cell proliferation"; Acta Facultatis Medicae Naissensis 30, 93-96, 2013.

[18] Ma, X.; Wang, Z.; "Anticancer drug discovery in the future: an evolutionary perspective"; Drug Discovery Today 14, 1136-1142, 2009.

[19] Zeng, Y. W.; Liu, X. Z.; Lv, Z. C.; Peng, Y. H.; "Effects of Ficus hirta Vahl. (Wuzhimaotao) extracts on growth inhibition of HeLa cells"; Experimental and Toxicologic Pathology 64, 743749, 2012 